\title{
Mycorrhization and saline stress response in Hyptis suaveolens
}

\section{Marília Cristina Gomes de Souza ${ }^{1}$ (iD) Marciana Bizerra de Morais ${ }^{1 *}$ (D) Marcelo da Silva Andrade ${ }^{1}$ (D) Mayron Alves de Vasconcelos ${ }^{1,2}$ (D) Silvana Saker Sampaio ${ }^{3}$ (D) Cynthia Cavalcanti de Albuquerque ${ }^{1}$ (iD}

${ }^{1}$ Programa de Pós-graduação em Ciências Naturais, Universidade do Estado do Rio Grande do Norte (UERN), 59600-000, Mossoró, RN, Brasil. E-mail: marciana.bio@gmail.com. "Corresponding author.

${ }^{2}$ Departamento de Patologia e Medicina Legal, Laboratório Integrado de Biomoléculas, Universidade Federal do Ceará (UFC), Fortaleza, CE, Brasil. ${ }^{3}$ Departamento de Engenharia de Pesca, Laboratório de Bioquímica Marinha, Universidade Federal do Ceará (UFC), Fortaleza, CE, Brasil.

ABSTRACT: The objective of this study was to evaluate the physiological and biochemical mechanisms of adaptation of Hyptis suaveolens under osmotic stress due to salinity inoculations with a mycorrhizal fungal species. H. suaveolens seeds were germinated in polyethylene pots containing a substrate associated with or without arbuscular mycorrhizal fungi (AMF). After plant formation, treatments were treated with different salt concentrations $(0.0,35,70$, and $105 \mathrm{mM})$ and fungi (control and two types of AMF), totaling 12 treatments with three replicates. The experimental design used randomized blocks in a $4 \times 3$ factorial scheme, totaling 12 treatments with three replicates each. Salinity affected all measured physiological and biochemical variables, and the stress reduced dry matter content. Plants associated with AMF had increased dry matter compared to non-associated plants, and there were increased biochemical and physiological responses of AMF-colonized plants in the $35 \mathrm{mM} \mathrm{NaCl}$ treatment. However, saline stress negatively affected the development of H. suaveolens; and therefore, no attenuation of fungi was observed.

Key words: antioxidant activity, abiotic stress, salinity, arbuscular mycorrhizal fungi.

Micorrização e resposta ao estresse salino em Hyptis suaveolens

RESUMO: Este estudo teve como objetivo avaliar mecanismos fisiológicos e bioquímicos de adaptação de Hyptis suaveolens submetidas ao estresse osmótico decorrente da salinidade inoculadas com espécies de fungos micorrízicos. Sementes de H. suaveolens foram colocadas para germinar em vasos de polietileno contendo substrato associado, ou não, a FMA. Após o estabelecimento das plantas, foram iniciados os tratamentos com diferentes concentrações de sais (0,0; 35; 70 e $105 \mathrm{mM}$ ) e fungos (controle e dois tipos de FMA), perfazendo 12 tratamentos com três repetições. O delineamento experimental foi em blocos casualizados em esquema fatorial $4 \times 3$, perfazendo 12 tratamentos com três repetições cada. Observou-se, através de variáveis fisiológicas e bioquímicas, que a salinidade afetou todas as variáveis analisadas e o estresse promoveu redução no conteúdo de matéria seca. Verificou-se que plantas associadas com FMA apresentaram ganho de matéria seca em relação as não associadas e incremento de respostas bioquímicas e fisiológicas das plantas colonizadas no tratamento $35 m M$ de NaCl. No entanto, o estresse salino afeta negativamente o desenvolvimento de H. suaveolens não sendo observado, portanto, atenuação dos fungos. Palavras-chave: atividade antioxidante, estresse abiótico, salinidade, fungos micorrízicos arbusculares.

\section{INTRODUCTION}

Hyptis suaveolens (L.) Poit is a weed from the Labiatae family, a subshrub with a wide geographical distribution in Brazil, but occurring more frequently in the Cerrado regions. It occurs annually and inhabits agricultural soils, roadsides, lands, and soil drastically changed by anthropogenic action. This species is widely distributed in tropical and subtropical regions (SAKTHIVADIVEL et al., 2015).
The species is recorded in the literature as a producer of an essential oil whose chemical composition consists mainly of monoterpenes, sesquiterpenes, alkanes, benzothiazole, diterpenes, triterpenes, and steroids (MARTINS, 2006). There are many studies on the action of this essential oil, which has proven antifungal, antibacterial, anticarcinogenic, and antiseptic properties (CHATRI et al., 2014), antioxidant effects (TAFURT-GARCÍA, 2015), and other actions. 
Plants are subject to various abiotic conditions in their natural habitat that change their metabolism. Due to the semiarid climate in the western region of Rio Grande Norte, the cultivation of important crops requires the use of fertigation, which over time salinizes and degrades the soil. This problem is associated with the abandonment of agricultural land, causing environmental damage and social problems (OLIVEIRA et al., 2019). To make use of these soils, it is necessary to investigate plant species that are adapted to semiarid conditions with the potential to generate income people living in the region. In this respect, the effect of saline stress has been extensively investigated.

Salinity causes major disturbances in most plant species, resulting in growth restriction and productivity loss, triggering an imbalance in the plant's redox system and causing physiological stress, which can impair growth and development (MORAIS et al., 2018; OLIVEIRA et al., 2019). A strategy that has been investigated to minimize the deleterious effects of excess salt in plants is the symbiotic association of plants with arbuscular mycorrhizal fungi (AMF). The symbiosis between plants and AMF is advantageous for both organisms, since plants provide fungi with energy products resulting from photosynthesis, allowing growth and maintenance; in turn, AMF provides the plant with water and nutrients such as phosphorus and nitrogen (HODGE; STORER, 2014). In this process, fungi associated with plant roots minimize damage and promote development through tolerance/resistance mechanisms (FOLLI-PEREIRA et al., 2012).

There are new possibilities to cultivate plants with economic potential that are adapted to high concentrations of salts and are able to maintain the production levels. The use of microorganisms may represent an option for expanding cultivation to saline areas. In view of this, the objective of the present study was to understand the physiological and biochemical mechanisms of adaptation of $H$. suaveolens to conditions of osmotic stress due to salinity when inoculated with mycorrhizal fungi species.

\section{MATERIALS AND METHODS}

Research was conducted in a greenhouse located in a semiarid region in the city of Mossoró, $\mathrm{RN}, 05^{\circ} 12^{\prime} 10^{\prime \prime}$ east and $37^{\circ} 18^{\prime} 57^{\prime \prime}$ west, with an average temperature of $35.9{ }^{\circ} \mathrm{C} \pm 2.7{ }^{\circ} \mathrm{C}$, natural photoperiod (approximately $12 \mathrm{~h}: 12 \mathrm{~h}$ light: dark), and a relative humidity of $49 \% \pm 5.5 \%$. According to the Köppen classification, the climate of the region is a BSW'h' type, characterized by being very hot and dry, with a rainy season in the summer that is delayed before the fall.

The arbuscular mycorrhizal fungi (AMF) Gigaspora albida and Claroideoglomus etunicatum were provided by the Federal Rural University of Pernambuco (UFRPE). They were multiplied in sand previously sterilized in an autoclave at 121 ${ }^{\circ} \mathrm{C}$ with pressure of $1 \mathrm{~atm}$ for one hour and placed in a forced circulation oven at $70{ }^{\circ} \mathrm{C}$ for two days, mixed with Vermiculite Expanded ${ }^{\circledR}$. To germinate them in a greenhouse, this mixture was distributed in pots containing Panicum miliaceum (Millet), a plant used as an AMF host. The substrate used in the experiment was the result of a mixture of washed sand, natural soil, and organic fertilizer in a 2:1:1 ratio, which was subsequently autoclaved at $121{ }^{\circ} \mathrm{C}$ with pressure of $1 \mathrm{~atm}$ for one hour to completely remove any microorganisms. After sterilization, the soil was dried for two days in a forced circulation oven at $70{ }^{\circ} \mathrm{C}$. After preparation, the substrates were characterized according to their physical and chemical characteristics (Table 1).

\section{Experimental strategy}

$H$. suaveolens seeds were collected, taken to the laboratory, selected and treated with chemical scarification with calcium oxide $(\mathrm{CaO})$ for dormancy. Then, 1,080 seeds were sown in 36 pots, totaling 30 seeds per pot. Thinning took place 30 days after sowing, leaving one plant per pot. The nutritional conditions of the substrate were maintained with the use of a nutrient solution (HOAGLAND \& ARNON, 1950) every five days throughout the cycle. After the acclimation period, the plants were treated with different sodium chloride $(\mathrm{NaCl})$ concentrations: 0.0 , 35,70 , and $105 \mathrm{mM}$, which corresponded to electrical conductivities of: $0.41,2.41,5.76$, and $8.47 \mathrm{dS} \mathrm{cm}^{-1}$ respectively. Plants were either inoculated with Gigaspora albida or Claroideoglomus etunicatum or not inoculated, and experienced systematic daily watering according to pot capacity (which was established using the capillarity method until the substrate was completely saturated). Pot capacity was considered as the water content retained in the soil after complete drainage.

The experimental statistical design was a $4 \times 3$ factorial arrangement in randomized blocks (four levels of $\mathrm{NaCl}$ and three treatments with fungi, including a control treatment and two types of AMF), totaling 12 treatments with three replicates. The Assistat ${ }^{\mathbb{B}}$ version 7.7 statistical software was used for the statistical analysis with ANOVA, and means were 
Table 1 - Physical and chemical characteristics of substrates inoculated with either Gigaspora albida or Claroideoglomus etunicatum.

\begin{tabular}{|c|c|c|c|}
\hline Characteristics & Natural soil & G. albida & C. etunicatum \\
\hline Texture & Sand & Sand & Sand \\
\hline Silt (\%) & 4.7 & 8.14 & 3.58 \\
\hline Clay (\%) & 0.78 & 2.47 & 0.32 \\
\hline Sand (\%) & 94.51 & 88.42 & 95.64 \\
\hline DA $\left(\right.$ g. $\left.\mathrm{cm}^{3}\right)$ & 1.53 & 1.47 & 1.51 \\
\hline $\mathrm{ST}(\mathrm{ppt})$ & 198.4 & 201 & 204 \\
\hline TSD (ppt) & 194.8 & 197.3 & 212.41 \\
\hline $\mathrm{N}\left(\mathrm{g} \mathrm{kg}^{-1}\right)$ & 3.01 & 1.75 & 2.38 \\
\hline $\mathrm{pH}\left(\mathrm{H}_{2} \mathrm{O}\right)$ & 7.70 & 7.00 & 7.40 \\
\hline $\mathrm{OM}\left(\mathrm{g} \mathrm{kg}^{-1}\right)$ & 20.98 & 19.45 & 21.20 \\
\hline $\mathrm{P}\left(\mathrm{mg} \mathrm{dm} \mathrm{m}^{-3}\right)$ & 273.6 & 241.6 & 242.2 \\
\hline $\mathrm{K}^{+}\left(\mathrm{mg} \mathrm{dm}-{ }^{3}\right)$ & 157.8 & 286.4 & 821.3 \\
\hline $\mathrm{Na}^{+}\left(\mathrm{mg} \mathrm{dm}-{ }^{3}\right)$ & 209.0 & 404.1 & 1009.9 \\
\hline $\mathrm{Ca}^{2+}\left(\mathrm{cmol}^{\mathrm{c}} \mathrm{dm}^{-3}\right)$ & 8.40 & 7.60 & 8.90 \\
\hline $\mathrm{Mg}^{2+}\left(\mathrm{cmol}^{\mathrm{c}} \mathrm{dm}^{-3}\right)$ & 0.80 & 4.10 & 2.40 \\
\hline $\mathrm{Al}^{3+}\left(\mathrm{cmol}^{\mathrm{c}} \mathrm{dm}^{-3}\right)$ & 0.00 & 0.00 & 0.00 \\
\hline $\mathrm{Cu}\left(\mathrm{mg} \mathrm{dm}^{-3}\right)$ & 0.31 & 1.27 & 0.75 \\
\hline $\mathrm{Fe}\left(\mathrm{mg} \mathrm{dm}^{-3}\right)$ & 13.8 & 45.3 & 48.7 \\
\hline $\operatorname{Mn}\left(m g \mathrm{dm}^{-3}\right)$ & 62.7 & 29.3 & 30.7 \\
\hline $\mathrm{Zn}\left(\mathrm{mg} \mathrm{dm}^{-3}\right)$ & 25.13 & 15.47 & 18.17 \\
\hline $\mathrm{H}^{+} \mathrm{Al}\left(\mathrm{cmol}^{\mathrm{c}} \mathrm{dm}^{-3}\right)$ & 0.00 & 0.33 & 0.00 \\
\hline $\mathrm{SB}\left(\mathrm{cmol}^{\mathrm{c}} \mathrm{dm}^{-3}\right)$ & 10.51 & 14.19 & 17.79 \\
\hline $\mathrm{t}\left(\mathrm{cmol}^{\mathrm{c}} \mathrm{dm}^{-3}\right)$ & 10.51 & 14.19 & 17.79 \\
\hline CTC & 10.51 & 14.52 & 17.79 \\
\hline V $(\%)$ & 100 & 98 & 100 \\
\hline $\mathrm{m}(\%)$ & 0 & 0 & 0 \\
\hline $\operatorname{PST}(\%)$ & 9 & 12 & 25 \\
\hline
\end{tabular}

compared using the Tukey test at 5\% significance. After collection, plant material was immediately frozen in liquid nitrogen and kept at $-20{ }^{\circ} \mathrm{C}$ for subsequent biochemical analysis.

\section{Evaluated variables}

Relative water content (RWC) was determined following the method by CAIRO (1995). In each replicate, six samples were taken from the central region of the penultimate leaf produced, packed in ice and immediately transferred to the laboratory. Fresh mass (FM) was determined using an analytical scale up to two hours after excision. These samples were then kept in deionized water for $24 \mathrm{~h}$ and, after removing excess water on filter paper, the turgid mass (TM) was obtained. After that, the samples were dried at $70{ }^{\circ} \mathrm{C}$ for $48 \mathrm{~h}$ to determine the dry mass (DM) of the tissue. RWC values were determined by the equation: (FM-DM)/ (TM-DM) x 100.
Plant material was dried in an oven with forced air circulation at $70{ }^{\circ} \mathrm{C}$ for $48 \mathrm{~h}$ to determine the dry biomass of the aerial part and root. Based on biomass values of the dry aerial part and root, the root/aerial part (R/AP) ratio was calculated according to BENINCASA (1988).

Proline content was quantified according to the method proposed by BATES et al. (1973) and the reducing sugars were determined using the 3,5-dinitrosalicylic (DNS) colorimetric method described by MILLER (1959). The standard curve of the spectrophotometric determination of reducing sugars was prepared using the standard 1 g. $\mathrm{L}^{-1}$ of glucose.

The analysis of chloroplast pigments (chlorophyll and carotenoids) was determined by the $80 \%$ acetone extraction method, according to LICHTENTHALER \& WELLBURN (1983). Absorbance readings of the samples obtained in a spectrophotometer at wavelengths 470, 645 and 663 
nm were used to calculate $\mathrm{a}, \mathrm{b}$ and total chlorophyll levels (WITHAM et al.,1971).

Lipid peroxidation was determined according to HEATH \& PACKER (1968), with modifications, where the reaction was determined through the production of malondialdehyde (MDA), a metabolite reactive to 2-thiobarbituric acid (TBA), and the percentage of membrane damage (MD) was estimated by the equation: \%MD = (L1/L2) x 100, estimated by electrolyte leakage (\%EL) and measured according to BLUM \& EBERCON (1981). Antioxidant activity, which is measured by the ability to sequester the DPPH radical (2,2-diphenyl-1-picrylhydrazyl - Sigma D9132), was determined according to DUAN et al. (2006), with some modifications.

The PHILLIPS \& HAYMAN (1970) methodology was modified and used to evaluate the percentage of mycorrhizal colonization, where thin roots were diaphanized in $2 \% \mathrm{KOH}$ at $90{ }^{\circ} \mathrm{C}$ in a water bath for 20 minutes, acidified in $1 \% \mathrm{HCl}$ in a water bath for four minutes and then colored with $0.05 \%$ trypan blue in lactoglycerol at $90{ }^{\circ} \mathrm{C}$ in water bath for ten minutes. Colonization rate was estimated using the slide method by GIOVANETTI $\&$ MOSSE (1980).

\section{RESULTS AND DISCUSSION}

There was a significant interaction between dry biomass of the aerial part, dry biomass of the root, and the R/AP ratio (ANOVA; $<<0.01$ ) (Table 2). When subjected to different levels of salinity, $H$. suaveolens showed a marked reduction in biomass production, with the roots more affected than the aerial part (Figure 1A and 1B), probably due to direct contact of the roots with the salt in the soil and corroborating the results by RAGAGNIN et al. (2014). This fact affected the R/AP ratio (Figure $1 \mathrm{C})$. The reduced growth rate of the plants was attributed to photosynthetic rate restrictions due to lower stomatal conductance and the consequent limitation in $\mathrm{CO}_{2}$ absorption capacity, as well as stress directly affecting cell division and expansion, which suppressed plant development (MORAIS et al., 2018). Visual symptoms characterized by chlorosis followed by necrosis were seen in basal and median $H$. suaveolens leaves as a result of saline stress toxicity. These symptoms in stressed leaves probably occurred due to the ionic stress caused by toxic levels of saline ions in leaf tissue (OLIVEIRA et al., 2019).

Although, the plants were negatively affected by salt, the association of plants with mycorrhizal fungi significantly increased dry matter in the aerial part compared with non-associated plants, especially at the highest salt concentrations (Figure 1A). The initial growth reduction caused by excess sodium is often associated with osmotic stress, which can cause a loss of RWC that results in decreased cell turgor (MUNNS, 2002), as observed in this study (Figure 1D). In a second step, growth reduction is attributed to $\mathrm{Na}^{+}$accumulation in tissues, which is toxic and results in chlorosis and necrosis, as seen in plants under severe stress (MORAIS et al., 2019; OLIVEIRA et al., 2019).

Salinity proportionally reduced biomass production in plants, with a reduction up to about $50 \%$ in the most severe treatment, regardless of whether or not they were inoculated with AMF; however, plants associated with $C$. etunicatum had greater biomass under the same stress conditions (Figure 1A and $1 \mathrm{~B})$. In this regard, some of the AMF benefits

Table 2 - Summary of the analysis of variance of the evaluated characteristics dry aerial part biomass (DAPB), dry root biomass (DRB) and root/aerial part ratio (R/AP) in Hyptis suaveolens subjected to different salt concentrations associated with mycorrhizal fungi.

\begin{tabular}{|c|c|c|c|c|}
\hline Variation Factor & GL & DAPB (g) & DRB(g) & $\mathrm{R} / \mathrm{AP}$ \\
\hline Fungi (F1) & 2 & $76.3959^{* *}$ & $29.4694^{* *}$ & $15.2949^{* *}$ \\
\hline Salinity (F2) & 3 & $623.2078^{* *}$ & $680.5532^{* *}$ & $19.4823^{* *}$ \\
\hline $\mathrm{F} 1 \mathrm{xF} 2$ & 6 & $83.7608^{* *}$ & $31.2306^{* *}$ & $15.6909^{* *}$ \\
\hline Treatments & 11 & $229.5436^{* *}$ & $207.9983^{* *}$ & $16.6529^{* *}$ \\
\hline \multirow[t]{2}{*}{ Blocks } & 2 & $0.6319^{\mathrm{ns}}$ & $0.5116^{\mathrm{ns}}$ & $2.0248^{\mathrm{ns}}$ \\
\hline & & 5.33 & 6.15 & 13.00 \\
\hline
\end{tabular}

${ }^{* *}$ Tukey test at $1 \%$ probability was applied ${ }^{*}$ Tukey test at $5 \%$ probability was applied. 


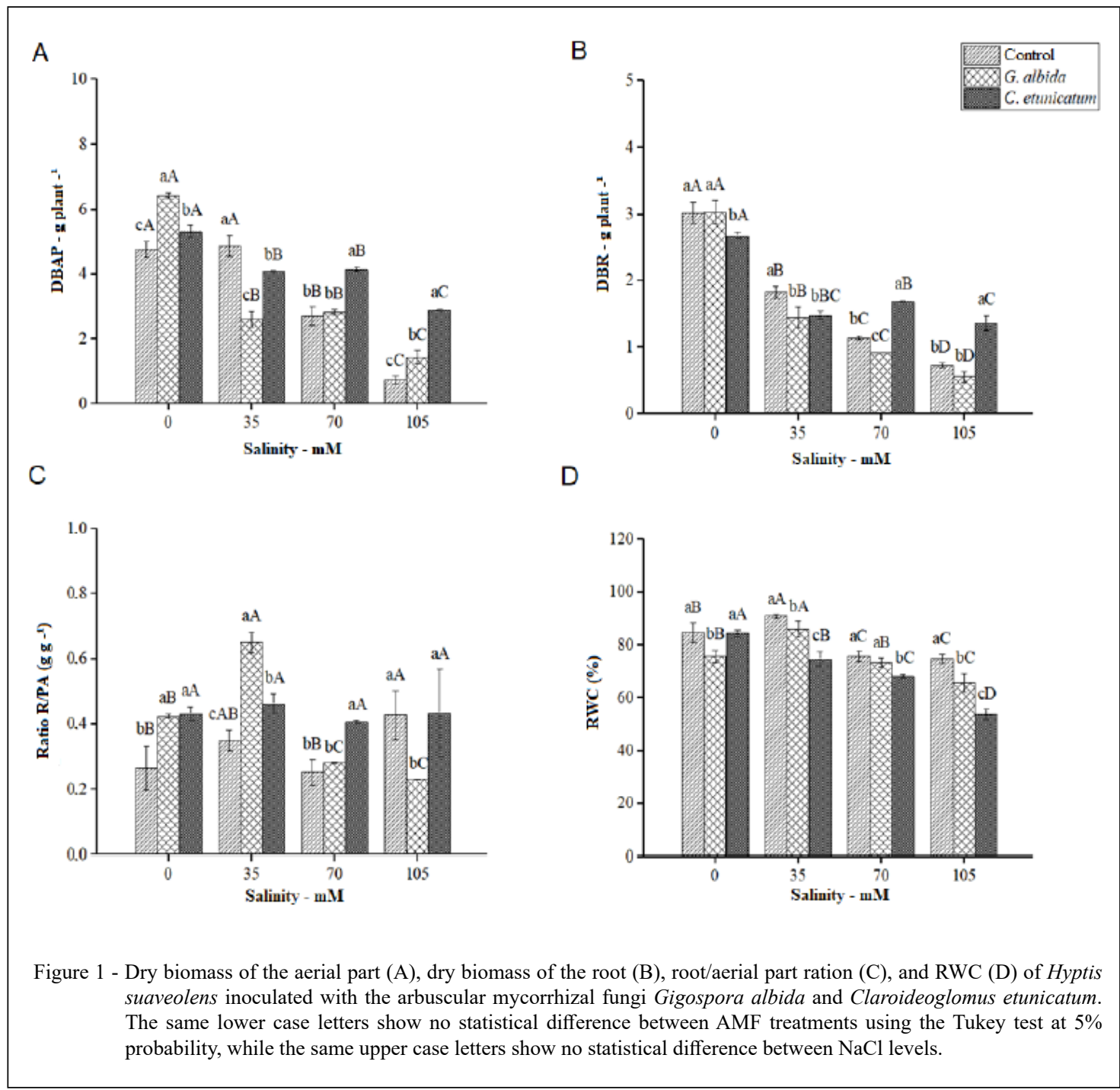

are a greater availability of nutrients to plants and a compartmentalization of $\mathrm{Na}^{+}$in hyphae, which can reduce the damage caused by excess salts (GUTJAHR \& PARNISKE, 2013). Studies with melon plants (Cucumis melo) under high salt concentrations showed decreased dry biomass production in aerial parts (LUCIO et al., 2013). However, the authors observed that when inoculated with AMF, plants had increased dry matter, despite the salt.

The results suggested that $75 \mathrm{mM} \mathrm{NaCl}$ is already a toxic level for $H$. suaveolens, as the plant stopped growing to deal with the level of stress. There was decreased RWC (Figure 1D), increased membrane damage (Figure 2A) and MDA accumulation (Figure 2B), with the accumulation of osmoregulators, such as proline, in an attempt to minimize the effects of saline stress (Figure 2C). This scenario can be attributed to oxidative damage caused by stress. Ionic stress in the protoplasm results in high levels of toxicity and disturbances related to ionic balance, changing the structure and stability of cell membranes (SHABALA et al., 2012).

The RWC is completely associated with the water retention capacity of the plant, and the higher this value, the better the water status of plant tissue. Studies of plants inoculated with AMF showed a relatively higher RWC compared to plants that were not inoculated (COLLA et al., 2008). As for lipid peroxidation, MDA has been considered a common biomarker of $\mathrm{NaCl}$ toxicity in plants. Lycopersicon esculentum inoculated with Glomus mosseae under 

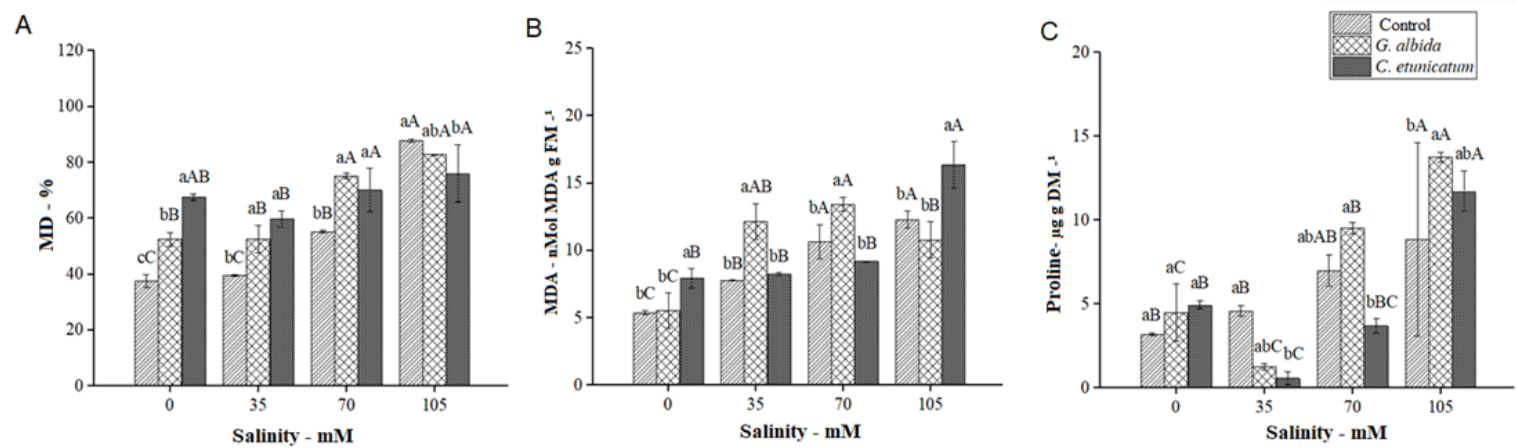

Figure 2 - Levels of membrane damage (MD) (A), lipid peroxidation (B), and proline (C) in leaves of Hyptis suaveolens inoculated with the arbuscular mycorrhizal fungi Gigospora albida and Claroideoglomus etunicatum. The same lower case letters show no statistical difference between AMF treatments using the Tukey test at 5\% probability, while the same upper case letters show no statistical difference between $\mathrm{NaCl}$ levels.

different salinity levels showed reduced MDA content (LATEF \& CHAOXING, 2011). In this study, the significantly increased MDA content in more severe treatments showed metabolic damage occurred and reflected the effects of oxidative stress.

Increased proline when exposed to salinity was also reported in another study (SARWAT et al., 2016). When plants were subjected to excess salts, they triggered osmotic adjustment mechanisms to maintain cell turgidity. The accumulation of this solute is a sensitive physiological indicator of plant responses to salt and other stresses (GUERZONI et al., 2014), as it also has other functions such as maintaining and protecting the integrity of the plasma membrane (MARIJUAN \& BOSCH, 2013).

In plants, sugar is used in growth-related metabolism by providing energy through the biological oxidation process (MORAIS et al., 2019). The increase in carbohydrates observed in severe salinity stresses (70 $\mathrm{mM}$ and $105 \mathrm{mM}$ ) may reflect an accumulation of osmoregulators in order to minimize the effects of stress (Figure 3B). High concentrations

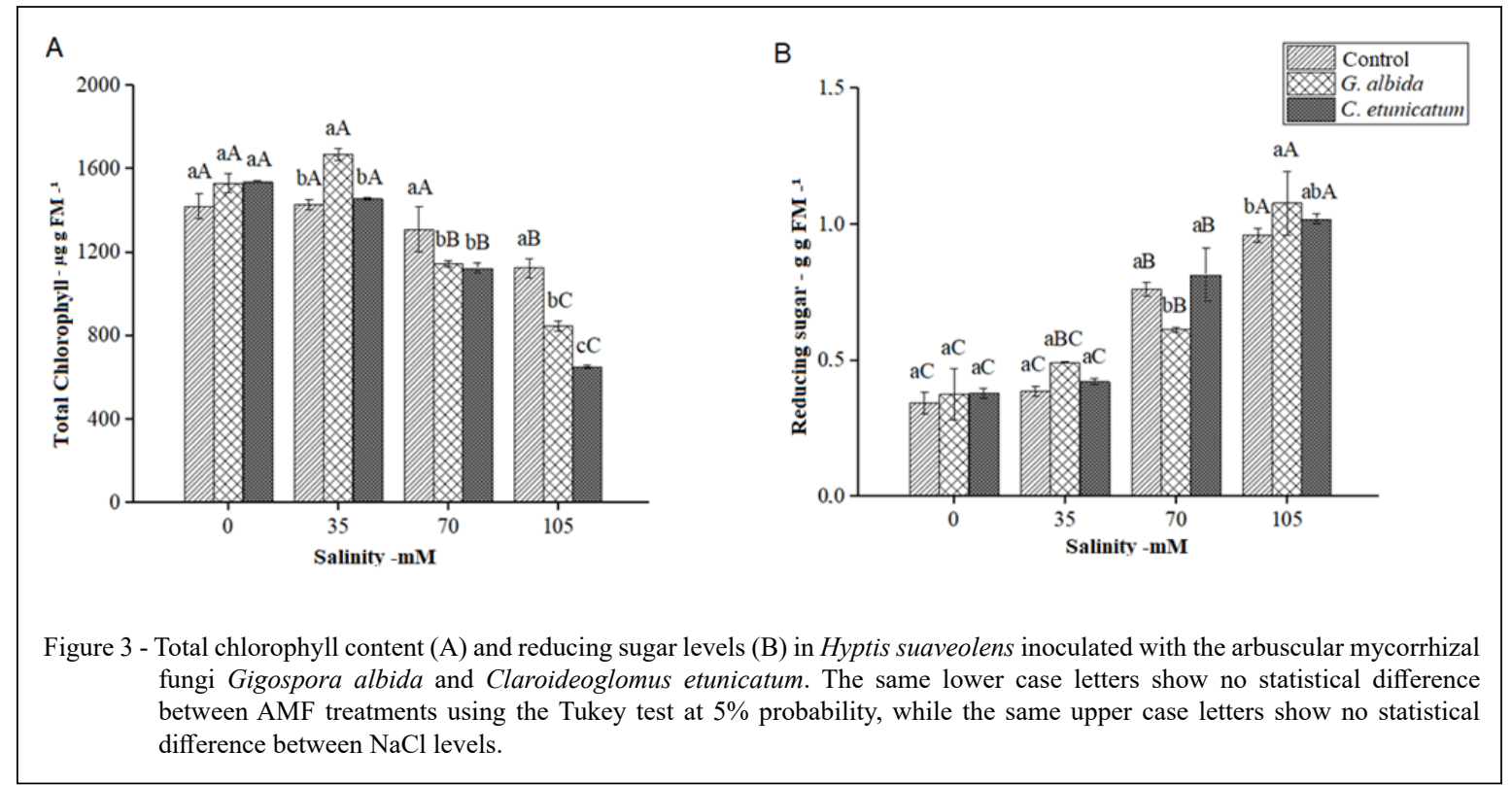

Ciência Rural, v.50, n.6, 2020. 
of reducing sugars stabilize some macromolecular structures of the cells, which helps to restore plasma membrane integrity. Of the various organic osmolytes, sugars provide about $50 \%$ or more of the total osmotic potential of glycophytes under abiotic stresses, in addition to preventing dehydration and being a source of energy for active cells under stress conditions (ELAVUMOOTTIL et al., 2003).

The plants were able to remain photosynthetically active under moderate salinity conditions (35 mM) (Figure 3A), which is considered important for plant development under stress and is usually treated as an important variable when determining salinity tolerance (MORAIS et al., 2019). However, more severe conditions had adverse effects on chlorophyll content, with saline stress causing a reduction in pigment content. ARAGÃO et al. (2009) proved that increased salt levels in the soil negatively influenced chlorophyll production in melon plants (C.melo L.); according to the authors, this contributed to a decreased production of fresh and dry matter by the plants.

When colonized with the two species of fungi, $H$. suaveolens presented structures characteristic of mycorrhizal colonization in all treatments regardless of salt dose, including arbuscules, hyphae, and vesicles (data not shown). Colonization was null in non-inoculated plants, showing that the soil sterilization method was effective (Figure 4A).
The evaluation of antioxidant activity (\% AA) in the aqueous extract of $H$. suaveolens leaves showed that all treatments presented DPPH sequestering activity, with DPPH sequestration above 80\% (Figure 4B), indicating that the species already has a complex antioxidant defense system regardless of stress. This system involved the activity of enzymes and nonenzymatic metabolites, which, jointly, eliminate ROS and reduce damage (BARBOSA et al., 2014).

The level of toxicity generated by salinity is a worldwide agricultural and environmental problem. In this sense, our study showed that stress severity may have affected AMF development (AGGARWAL et al., 2012). The necrotic points visualized in the plants treated with $\mathrm{NaCl}$ may be related to ion accumulation, since excess ions result in morphological changes (smaller leaves and fewer leaves) and even cell death. However, it is worth mentioning that despite the evidence of oxidative stress, the plants had higher dry biomass content when inoculated with $C$. etunicatum in the most severe stress scenario, suggesting an attenuation of the effects of stress, which corroborates with the literature on the performance of this fungus in relation to better absorption of water and nutrients, better nutrition, greater contents of reserve substances, and greater vegetative development of plants when considering physiological mechanisms (SILVEIRA et al., 2002; FERNANDES et al., 2019).

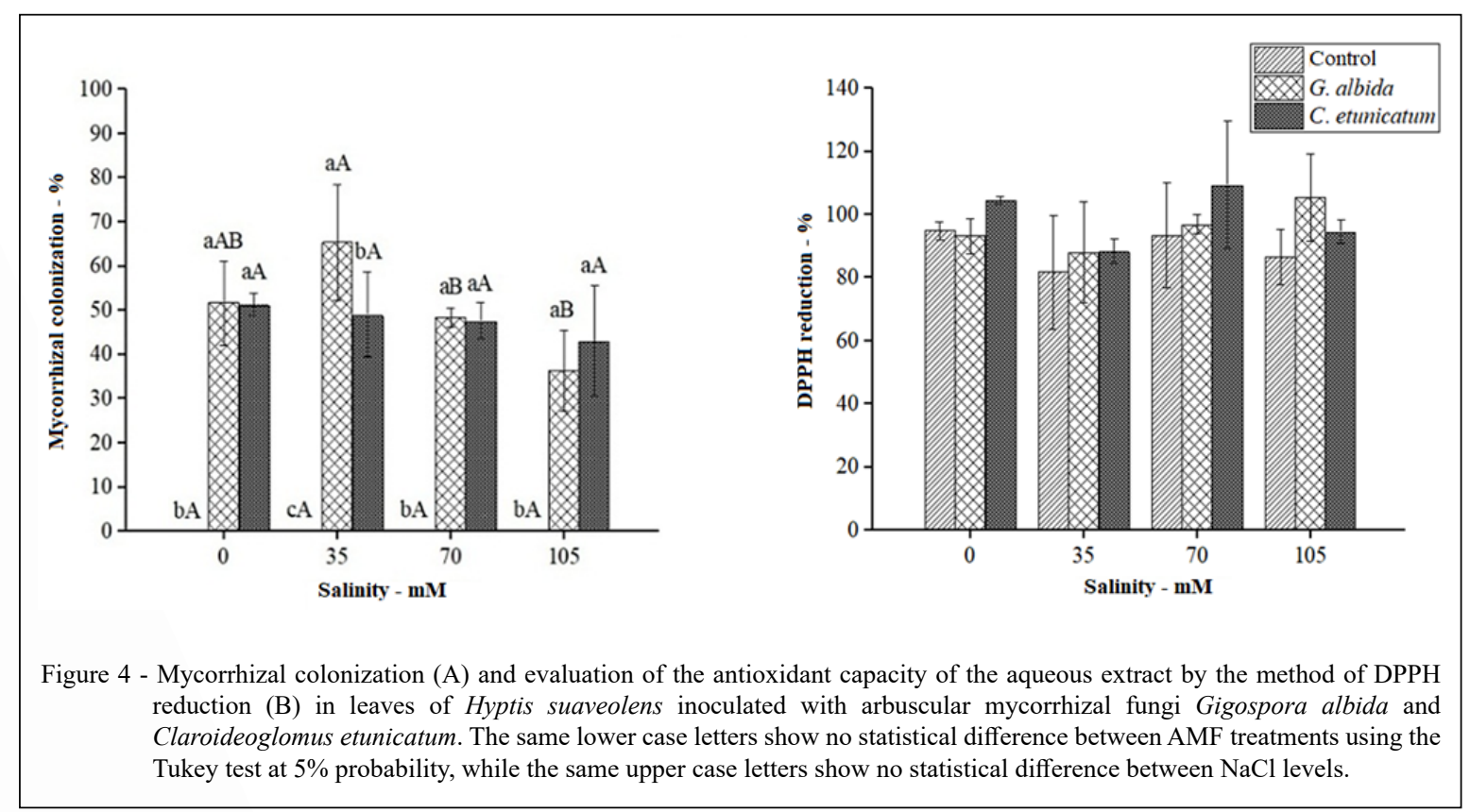

Ciência Rural, v.50, n.6, 2020. 


\section{CONCLUSION}

Osmoregulatory mechanisms and antioxidant activity did not prevent MD due to the severity of salt stress, which negatively interfered with the development of $H$. suaveolens. However, the fungus $C$. etunicatum improved the physiological performance of plants experiencing salt stress.

\section{DECLARATION OF CONFLICT OF INTERESTS}

The authors declared no potential conflicts of interest with respect to the research, authorship, and/or publication of this article.

\section{ACKNOWLEDGEMENTS}

The authors gratefully acknowledge the Universidade do Estado do Rio Grande do Norte, Universidade Federal Rural de Pernambuco (UFRPE) and Coordenação de Aperfeiçoamento de Pessoal de Nível Superior (CAPES) for support.

\section{AUTHORS' CONTRIBUTIONS}

MCGS participated in the data collection, designed the experiments, data analysis wrote the manuscript, MBM participated in the interpretation, review the article and provided editorial advice; MSA, MAV and SSS realization of analyses physiological and biochemistry interpretation and analyzed data; CCA guided every step of the work and participated in the drafting and review of the project and of the article.

\section{REFERENCES}

AGGARWAL, A. et al. Arbuscular mycorrhizal symbiosis and elleviation of salinity stress. Journal of Applied and Natural Science, v.4, n.1, p.144-155, 2012. Available from: <https://journals.ansfoundation.org/index.php/jans/ article/view/239/217>. Accessed: Jun. 10, 2019. doi: $10.31018 /$ jans.v4i1.239.

ARAGÃO, C.A. et al. Evaluation of melon cultivars under salt stress. Revista Caatinga, v.22, n.2, p.161-169, 2009. Available from: $<$ https://www.cabdirect.org/cabdirect/abstract/20093348977>. Accessed: Feb. 07, 2018.

BARBOSA, M. et al. Geração e desintoxicação enzimática de espécies reativas de oxigênio em plantas. Ciência Rural, Santa Maria, v.44, n.3, p.453-460, 2014. Available from: <http://www. scielo.br/pdf/cr/v44n3/a7914cr2013-0032.pdf $>$. Accessed: Jan. 05, 2019. doi: 10.1590/S0103-84782014000300011.

BATES, L.; WALDREN, R. P.; TEARE, I. D. Rapid determination of free proline for water-stress studies. Plant and Soil. v.39, p.205-207, 1973. Available from: <https://link.springer.com/ article/10.1007/BF00018060>. Accessed: Jan. 28, 2019. doi: 10.1007/BF00018060.

BENINCASA, M. M. P. Análise do crescimento de plantas. Jaboticabal: FUNEP, 1988. 42p.
BLUM, A.; EBERCON, A. Cell membrane stability as a measure of drought and heat tolerance in wheat. Crop Science. v.21, p.43-47, 1980. Available from: <http://eprints. icrisat.ac.in/1521/>. Accessed: Jun. 10, 2019. doi: 10.2135/ cropsci1981.0011183X002100010013x.

CAIRO, P. A. R. Curso básico de relações hídricas de plantas. Editora UESB, Vitória da conquista. 1995; 32p.

CHATRI, M.; et al. Chemical Components of Essential Oils of the Leaves of Hyptis suaveolens (L.) Poit from Indonesia. American Journal of Research Communication, v.2, n.10, p.30-38, 2014. Available from: <http://www.usajournals.com/wp-content/uploads/2014/09/Chatri_Vol210. pdf>. Accessed: Jun. 10, 2019. doi: 10.1590/S151783822010000100006 .

COLLA, G. et al. Alleviation of salt stress by arbuscular mycorrhizal in zucchini plants grown at low and high phosphorus concentration. Biology and Fertility of Soils, v.44, p.501-509, 2008. Available from: <file:///C:/Users/DELL/Downloads/BFS2008.pdf>. Accessed: Jun. 08, 2019. doi: 10.1007/s00374-007-0232-8.

DUAN, X. J. et al. Evaluation of antioxidant property of extract and fractions obtained from a red alga, Polysiphonia urceolata. Food Chemistry, v.95, p.37-43, 2006. Available from: <https://www.sciencedirect.com/science/ article/pii/S0308814605000282>. Accessed: Jan. 10, 2019. doi: 10.1016/j.foodchem.2004.12.015.

ELAVUMOOTTIL, O. C; et al. Changes in sugars, sucrose synthase activity and proteins in salinity tolerant callus and cells supersion cultures of Brassica oleraceae L. Biology Plant, v.46, p.7-12, 2003. Available from: <https://link.springer.com/artic le/10.1023/A:1022389428782>. Accessed: Jan. 09, 2019. doi: 10.1023/A:1022389428782.

FERNANDES, M. D. S. S.; et al. Arbuscular mycorrhizal fungi and auxin associated with microelements in the development of cuttings of Varronia leucocephala. Revista Brasileira de Engenharia Agrícola e Ambiental, v.23, p.167-174, 2019. Available from: $<$ http://www.scielo.br/scielo.php?script=sci_arttext\&pid=S141543662019000300167\&lng=en\&nrm=iso\&tlng=en>. Accessed: Jun. 08, 2019. doi: 10.1590/1807-1929/agriambi.v23n3p167-174.

FOLLI-PEREIRA, M. S. et al. Micorriza arbuscular e a tolerância das plantas ao estresse. Revista Brasileira de Ciência do Solo, v.36, p.1663-1679, 2012. Available from: <http://www.scielo.br/ scielo.php?script $=$ Sci_arttext\&pid $=$ S0100-06832012000600001 $>$. Accessed: Jan. 05, 2019. doi: 10.1590/S0100-06832012000600001.

GIOVANETTI, M.; MOSSE, B. An evaluation of techniques for measuring vesicular arbuscular mycorrhizal infection in roots. New Phytologist, v.84, p.489-500, 1980. Available from: $<$ https:// nph.onlinelibrary.wiley.com/doi/epdf/10.1111/j.1469-8137.1980. tb04556.x>. Accessed: Jun. 07, 2019. doi: 10.1111/j.14698137.1980.tb04556.x.

GUERZONI, J. T. S. et al. Stressinduced D1-pyrroline-5carboxylate synthetase (P5CS) gene confers tolerance to salt stress in transgenic sugarcane. Acta Physiologiae Plantarum, v.36, p.309-2319, 2014. Available from: <https://www.researchgate. net/publication/271660571 Stress-induced D1-pyrroline-5carboxylate_synthetase_P5CS__gene_confers_tolerance_to_salt_ stress_in_transgenic_sugarcane $>$. Accessed: Feb. 05, 2019. doi: $10.1007 / \mathrm{s} 11738-014-1579-8$. 
GUTJAHR, C.; PARNISKE, M. Cell and developmental biology of arbuscular mycorrhiza symbiosis. Annu Rev Cell Dev Biol, v.29, p.593-617, 2013. Available from: $<$ https://www.annualreviews.org/doi/10.1146/annurevcellbio-101512-122413>. Accessed: Jan. 05, 2011. doi: 10.1146/ annurev-cellbio-101512-122413.

HEATH, R. L, PACKER, L. Photoperoxidation in isolated Chloroplasts. I. Kinetics and stoichiometry of fatty acid peroxidation. Archives of Biochemistry and Biophysics, v.125, p.189-198, 1968. Available from: <https://www.sciencedirect. com/science/article/abs/pii/0003986168906541>. Accessed: Jun. 11, 2019. doi: 10.1016/0003-9861(68)90654-1.

HOAGLAND, D. R.; ARNON, D. I. The water culture method for growing plants without soils. Berkeley: California Agricultural Experimental Station, 347p., 1950. Available from: <https:// sayurankitadotcom.files.wordpress.com/2016/04/the-waterculture-method-for-growing-plants-without-soil.pdf $>$. Accessed: Feb. 10, 2011

HODGE, A.; STORER, K. Arbuscular mycorrhiza and nitrogen: Implications for individual plants through to ecosystems. Plant Soil, v.386, p.1-19, 2014. Available from: <https://link.springer. com/article/10.1007/s11104-014-2162-1>. Accessed: Feb. 01, 2011. doi: 10.1007/s11104-014-2162-1.

LATEF, A.A.H.A.; CHAOXING, H. Effect of arbuscular mycorrhizal fungi on growth, mineral nutrition, antioxidant enzymes activity and fruit yield of tomato grown under salinity stress. Scientia Horticulturae, v.127, n.3, p.228-233, 2011. Available from: <http://agris.fao.org/agris-search/search. do?recordID=US201301921257>. Accessed: Jun. 10, 2011. doi 10.1016/j.scienta.2010.09.020.

LICHTENTHALER, H.; WELLBURN, A. Determinations of total carotenoids and chlorophylls $\mathrm{b}$ of leaf extracts in different solvents. Biochemical Society Transactions, v.11: 591-592, 1983. Available from: <https://portlandpress.com/biochemsoctrans/ article-abstract/11/5/591/57549/Determinations-of-totalcarotenoids-and?redirectedFrom $=$ fulltext $>$. Accessed: Jan. 08, 2019. doi: 10.1042/bst0110591.

LÚCIO, W. S. et al. Growth and physiological responses of melon plants inoculated with mycorrhizal fungi under salt stress. Semina: Ciências Agrárias, v.34, n.4, p.1587-1602, 2013. Available from: <http://www.uel.br/revistas/uel/index. php/semagrarias/article/view/10677/13048>. Accessed: Jun. 09, 2019. doi: 10.5433/1679-0359.2013v34n4p1587.

MARTINS, F. T. et al. Chemical variation in the essential oil of Hyptis suaveolens (L.) Poit., under cultivation condition. Química Nova, v.29, p.1203-9, 2006. Available from: <http://www.scielo. $\mathrm{br} / \mathrm{sciel}$. php?pid $=\mathrm{S} 0100-40422006000600011 \& \mathrm{script}=\mathrm{sci}$ abstract>. Accessed: Feb. 15, 2019. doi: 10.1590/S010040422006000600011.

MARIJUAN, M. P.; BOSCH, S. M. Ecophysiology of invasive plants: osmotic adjustment and antioxidants. Trends in Plant Science, v.18, p.660-666, 2013. Available from: <https://www. ncbi.nlm.nih.gov/pubmed/24001766>. Accessed: Apr. 10, 2011. doi: $10.1016 / j$.tplants.2013.08.006

MILLER G. L. Use of dinitrosalicylle acid for determination of reducing sugar. Analytical Chemintry, v.11, p.426-428, 1959. Available from: <https://pubs.acs.org/doi/abs/10.1021/ ac60147a030>. Accessed: Dec. 28, 2018. doi: 10.1021/ ac60147a030

MORAIS, M. B. et al. Multiple stresses on the oxidative metabolism of sugarcane varieties. Ciência Rural, v.48, p.1-8, 2018. Available from: $\quad<$ http://www.scielo.br/scielo.php?script=sci_arttext\&pid $=$ S0103-84782018000400201 $>$. Accessed: Feb. 25, 2019. doi: $10.1590 / 0103-8478 \mathrm{cr} 20141487$.

MORAIS, M. B. et al. Salt Stress Induces Increase in Starch Accumulation in Duckweed (Lemna aequinoctialis, Lemnaceae): Biochemical and Physiological Aspects. Journal of Plant Growth Regulation, v.38, p.683-700, 2019. Available from: <https://link.springer.com/article/10.1007/ s00344-018-9882-z>. Accessed: Jun. 20, 2019. doi: 10.1007/ s00344-018-9882-z.

MUNNS, R. Comparative physiology of salt and water stress. Plant Cell Environment, v.25, p.239-250, 2002. Available from: $<$ https:// onlinelibrary.wiley.com/doi/pdf/10.1046/j.0016-8025.2001.00808. x>. Accessed: Jun. 11, 2019. doi: 10.1046/j.0016-8025.2001.00808.x.

PHILLIPS, J. M.; HAYMAN, D. S. Improved procedures for clearingf roots and staining parasitic and vesicular-arbuscular mycorrhizal fungi for rapid assessment of infection. Transactions of British Mycological Society, v.55, p.158-161, 1970. Available from: $\quad<$ https://www.sciencedirect.com/science/article/pii/ S0007153670801103>. Accessed: Jan. 20, 2019. doi: 10.1016/ S0007-1536(70)80110-3.

OLIVEIRA, F. F. M. et al. Ecophysiological response of Lippia gracilis (Verbanaceae) to duration of salt stress. Ecotoxicology and Environmental Safety, v.178, p.202-210, 2019. Available from: <https://www.sciencedirect.com/science/article/abs/pii/ S0147651319304294?via\%3Dihub>. Accessed: Jun. 19, 2019. doi: 10.1016/j.ecoenv.2019.04.016.

RAGAGNIN, R. C. G. et al. Effect of salt stress on the growth of Lippiagracilis Schauer and on the quality of its essential oil. Acta BotanicaBrasilica, v.28, p.346-351, 2014. Available from: <http://www.scielo.br/scielo.php?script=sci arttext\&pid=S0102-33062014000300006 $>$. Accessed: Jan. 11, 2019. doi: 10.1590/0102-33062014abb3369.

SAKTHIVADIVEL, M. et al. Mosquito larvicida lactivity of Hyptis suaveolens (L.) Poit (Lamiaceae) aerial extracts against the filarial vector Culex quinquefasciatus Say (Diptera: Culicidae). Journal of Medicinal Plants Studies, v.3, n.4 p.1-5, 2015. Available from: <http://www.plantsjournal. com/vol3Issue4/Issue_july_2015/3-3-12.1.pdf $>$. Accessed: Jun. 10, 2019.

SARWAT, M. et al. Mitigation of nacl stress by arbuscular mycorrhizal fungi through the modulation of osmolytes, antioxidants and secondary metabolites in mustard (Brassica juncea L.) plants. Frontiers in Plant Science. v.7, p.869, 2016. Available from: <https://www.frontiersin.org/articles/10.3389/ fpls.2016.00869/full>. Accessed: Jun. 15, 2019. doi: 10.3389/ fpls.2016.00869.

SHABALA, L. et al. Oxidative stress protection and stomatal patterning as components of salinity tolerance mechanism in quinoa (Chenopodium quinoa). Physiologia Plantarum, n.1, p.1-13, 2012. Available from: <https://www.ncbi.nlm.nih.gov/ pubmed/22324972>. Accessed: Dec. 27, 2018. doi: 10.1111/j.13993054.2012.01599.x 
SILVEIRA, S. V.; SOUZA, P. V. D.; KOLLER, O. C. Influence of arbuscular mycorrhizal fungi on vegetative growth of avocado rootstocks. Pesquisa Agropecuária Brasileira, v.37, p.303-309, 2002. Available from: $<$ http://www.scielo.br/scielo.php?script=sci arttext\&pid=S0100-204X2002000300011 >. Accessed: Jun. 10, 2011. doi: 10.1590/S0100-204X2002000300011.

TAFURT-GARCÍA, G.; et al. Antioxidant capacity and total phenol content of Hyptis spp., P. heptaphyllum, T. panamensis,
T. rhoifoliaand Ocotea sp. Revista Colombiana de Química, v.44, p.28-33, 2015. Available from: <http://www.scielo.org.co/ scielo.php?script $=$ sci_arttext\&pid=S0120-28042015000200005>. Accessed: Jun. 10, 2011. doi: 10.15446/rev.colomb.quim. $\mathrm{v} 44 \mathrm{n} 2.55217$.

WITHAM, F. H.; et al. Experiments in plant physiology. Ne: D.V. Nostrand; 1971. Available from: <https://lib.ugent.be/catalog/ rug01:001190680>. Accessed: Jun. 27, 2018. 